\title{
Effects of Van Hiele's Phase-based Teaching Strategy and Gender on Retention of Achievement in Geometry among Pre-service Mathematics Teachers' in Niger State, Nigeria
}

\author{
Hassan Usman ${ }^{1 *}$ (), Wun Thiam Yew ${ }^{2}$ (), Salmiza Saleh 2 (1)
}

${ }^{1}$ Niger State College of Education, Minna, NIGERIA

${ }^{2}$ School of Educational Studies, Universiti Sains Malaysia, MALAYSIA

*Corresponding Author: babanibro73@gmail.com

Citation: Usman, H., Yew, W. T., \& Saleh, S. (2020). Effects of Van Hiele's Phase-based Teaching Strategy and Gender on Retention of Achievement in Geometry among Pre-service Mathematics Teachers' in Niger State, Nigeria. International Journal of Pedagogical Development and Lifelong Learning, 1(2), ep2009. https://doi.org/10.30935/ijpdll/9139

\begin{abstract}
This study investigated the effects of Van Hiele's phase-based teaching strategy on retention of achievement among pre-service mathematics teachers in Niger State, Nigeria. It also examined the influence of gender and interaction effects of teaching method and gender on retention of achievement. The study adopts a two-by-two (2X2) pretest posttest quasi experimental factorial design. 149 pre-service mathematics teachers from two colleges of education in Niger State were purposively selected for the study. Geometry Achievement Test (GAT) was used for data collection. The reliability coefficient of 0.78 was obtained using Cronbach alpha. GAT was administered to preservice mathematics teachers as pretest, posttest and retention test. The pre-service mathematics teachers' retention test scores were analysed using Analysis of Covariance (ANCOVA). The results indicated that the preservice mathematics teachers' taught geometry using van Hiele's phase-based teaching strategy retained significantly what was taught better in retention test than their counterparts taught geometry using conventional teaching strategy. However, there was no significant difference reported in the retention test performance scores based on gender and interaction effect. It was however suggested that since the treatment (van Hiele's phase-based teaching strategy) were found to be effective in enhancing pre-service teachers' retention of achievement, it should therefore be use by lecturers in teaching not only geometry but mathematics in general.

This study investigated the effects of Van Hiele's phase-based teaching strategy on retention of achievement among pre-service mathematics teachers in Niger State, Nigeria. It also examined the influence of gender and interaction effects of teaching method and gender on retention of achievement. The study adopts a two-by-two (2X2) pretest posttest quasi experimental factorial design. 149 pre-service mathematics teachers from two colleges of education in Niger State were purposively selected for the study. Geometry Achievement Test (GAT) was used for data collection. The reliability coefficient of 0.78 was obtained using Cronbach alpha. GAT was administered to preservice mathematics teachers as pretest, posttest and retention test. The pre-service mathematics teachers' retention test scores were analysed using Analysis of Covariance (ANCOVA). The results indicated that the preservice mathematics teachers' taught geometry using van Hiele's phase-based teaching strategy retained significantly what was taught better in retention test than their counterparts taught geometry using conventional teaching strategy. However, there was no significant difference reported in the retention test performance scores based on gender and interaction effect. It was however suggested that since the treatment (van Hiele's phase-based teaching strategy) were found to be effective in enhancing pre-service teachers' retention of achievement, it should therefore be use by lecturers in teaching not only geometry but mathematics in general.
\end{abstract}

Keywords: geometry, gender, pre-service mathematics teachers, retention, Van Hiele's phase-based teaching strategy

Received: 7 Jul. $2020 \bullet$ Accepted: 9 Aug. 2020

\section{INTRODUCTION}

Mathematics as a discipline has since become the focal point of all the technological field of studies (Gambari \& Adegbenro, 2014). It is an area of studies that cannot be avoided as a result of its significance in shaping individual reasoning faculty most especially in this fast- changing world (Mata, Monteiro, \& Peixoto, 2012). In recent times, advances and reforms particularly in mathematics education has produced new innovations and claims with them (Uygun \& Tertemiz, 2014). Most notable of these claims and innovations are that it offers learners at all levels a considerable sphere of activities that gave rise to opportunities to reason and share information during the instructional processes (National Council of Teachers of Mathematics [NCTM], 
2000). Diverse learning strategies on the basis of these activities are employed particularly in learning and teaching processes. One of these learning strategies is "van Hiele's phase-based teaching strategy" (VHPBTS). The van Hiele's phase-based teaching strategy establishes learning process that facilitated learners thinking and reasoning progression specifically in geometry. Just like other teaching strategies, VHPBTS involves five thinking levels and five phases of instruction which previously has been used in many studies (Abdullah \& Zakaria, 2013b; Abu et al., 2012; Alex \& Mammen 2016; Atebe, 2008; Cannizaro \& Menghhni, 2006; Chang et al., 2007; Chew, 2007; Chew \& Lim, 2013; Erdogan \& Durmus, 2009; Fuys et al., 1988; Hoffer, 1983; Usiskin, 1982) that are connected with teaching and learning of geometry. It was however indicated from these researches that, VHPBTS was effective in improving students' academic achievement. The VHPBTS was nevertheless, perfected by two Dutch mathematicians in the 1950s, Pierre van Hiele and his wife Dina van Hiele-Geldof. According to van Hiele (1986) the levels are: Recognition, Analysis, Order, Deduction and Rigor.

These levels as mentioned, are achieved as a consequence of experience and instruction rather than age. Hence, for a student to shift to a higher stage of involvedness, such a student needs a sufficient knowledge of (classroom or otherwise) geometric thoughts. In other words, the characteristics of the model is classified. Each and every of the levels (levels 1 - 5) go together with five phases. Chew (2009) and Choi-Koh (2000) affirmed this by pronouncing that students are expected to undergo all the five phases to enable him/her to arrive at each of van Hiele's level. Accordingly, the five phases of instruction are: Information, Guided orientation, Explicitation, Free-orientation and Integration. Consequently, Yunus, Suraya, Ayub, and Fauzi (2019) admitted that when VPBTS is properly implemented by the teacher, it moves up level of geometry instruction process which as a result assisted in developing and improving retention of achievement.

Retention of achievement as defined by Gambari, Falode, and Adegbenro (2014) is the ability to reproduce what was previously learnt when the need arises. In the view of Bell and Kozlowski (2008), retention means direct relationship of progressive or positive knowledge already learned. To this end, therefore, it means that retention could give rise to high academic achievement which is an aspect of several variables like teaching strategies/methods, period between teaching and learning and recovery among others. In the view of Osemmwinyen (2009), an appropriate instructional strategy could arouse and retain student academic achievement. Therefore, since it has been established from researches such as Gambari, Falode, and Adegbenro (2014), Udousoro (2002) that findings have established inconsistence results on the variables that may lead to students retaining more of what they have learnt. More so, the interest of every teachers, particularly mathematics teachers, is to combine into teaching the significant addition created from the angle of edifying research, specifically as it concerns geometry teaching. In this way, the researcher will be offer with the opportunity to come up with effective teaching model. Hence, after through research on van Hiele theory of instruction, it was found out that one with an idea of van Hiele's phasebased teaching strategy can come up with actions and expose the learner to the understanding of geometry concepts. In addition, his geometry ideas will make available appropriate lessons structure and other apparatus. Unquestionably, it point toward offering the awareness to mathematics teaching of interconnecting components in-built for teaching geometry.
Gender and retention levels of pre-service mathematics teachers are one more area that was investigated in this study. It is a unique area of study which has been respectively recurring all over literatures in mathematics education and academic studies in general (Mata, Monteiro, \& Peixoto 2012). According to Hassan (2015), "the term gender is important in Science, Technology, and Mathematics (STM) because, it described the social definition of sex role rather than distinct biological distinction itself, STM is seen as subject of male and the female" (p. 42). Mathematics generally is frequently taking into consideration as one area in which males are considered to be higher achievers, in terms of both attitudes and self-concept (Mata, 2012). On the other hand, Lindberg, Hyde, Petersen, and Linn, (2010) and Scafidi and Bui (2010) in their separate results indicates that there is no substantial difference on mathematics achievement and grades based on gender. Finding relating to gender differences on attitudes is not stable. Few studies have stated significant differences upon comparing attitudes towards mathematics based on gender (Asante, 2012; Eshun, 2004). However, there exist quite a number of studies in which these differences are not noticeable (Mohamed \& Waheed, 2012). Therefore, there is need to examine the interaction effect of gender and geometry retention level within the Nigerian school context on students geometry achievement.

In view of this, the study attempted to determine the effects of van Hiele's phase-based teaching strategy and gender on pre-service mathematics teachers' retention of achievement in geometry in Niger state, Nigeria.

\section{LITERATURE REVIEW}

Failure on the part of the learner to recall or retain what was learnt, has been stressed from previous studies (e.g., Gambari, Falode, \& Adegbenro, 2014; Udousoro, 2002) as unique reason influencing learners' poor academic achievement in mathematics. Kurumeh, Onah, and Mohammed (2012) in their views maintained that incorrect, insufficient and restricted teaching strategy employed by mathematics teachers is responsible for learners' inability to comprehend and recollect the rudimentary mathematical principles and logical facts. As a result, this approach gave rise to learning by rote or memorization which subsequently resulted to poor retention, poor academic achievement and negative attitude towards mathematics. Gambari, Falode, and Adegbenro (2014), and Omenka (2010) ascribed the poor academic achievement of learners and retention level in mathematics predominantly among genders to teaching strategy employed by teachers. In view of this, appropriate teaching strategy was suggested to increase learners' retention and achievement.

Researching on retention and achievement in mathematics, Obi, Agwagah, and Agah (2014) investigated the effects of Origami teaching strategy on Junior secondary I students' retention in geometry. A quasiexperimental non-equivalent pretest, posttest, control group design was adopted. A sample of 101 junior secondary I students was involved (65 female and 36 male). The instrument for data collection was geometry retention test (GRT). Data collected were however, analyzed using descriptive and inferential statistics such as mean, standard deviation and analysis of covariance (ANCOVA). The result of the study revealed that use of Origami significantly enhanced retention of achievement of geometry among junior secondary school students. The study also revealed no statistically significant difference based on gender 
on retention of achievement. In addition, there was a significant interaction effect between gender and treatment on retention of the concepts taught during the study. Based on the findings, the researchers recommended that use of Origami should be adopted in the teaching of geometry (mathematics) in primary, secondary, and tertiary levels of education system.

In the study conducted by Khurana (2018) in Delhi India, to find out the impact of hands-on activities in mathematics in relation to achievement and concept retention. 164 pupils form the sample of the study. A self-made test of concept retention was employed for data collection and t-test statistics was used in data analysis. The result of the study indicates a significant difference favouring the experimental group. For the retention of achievement, a significant difference was also noticed in favor of experimental group. Confirming the work of Khurana (2018), Aliustaoğlu and Tuna (2018) affirmed that mathematics is seen by learners to be one of the abstract courses, then, non-application of suitable strategy might give rise to learners to inappropriately believe that mathematics is not important in day-to-day life, and as such restricted to textbooks only. To arrest the situation, transformations were made by introducing models in teaching and learning process. One of such models is "4MAT model". It was on this note that Aliustaoğlu and Tuna (2018) sought to find out the effects of 4MAT model in the teaching of "Transformation Geometry". 4MAT model, is one of the current instructional strategy which provides basis for learners to perceiving and processing knowledge. It was planned by taking into account the four learning styles in a way learner can discover a time interval appropriate for them. 61 high school students in a northern province of Turkey form the sample for the study. The study which lasted for three weeks adopted a pretest-posttest control group quasi-experimental design. The period of teaching was decided having in mind the time suggested in the textbook and the time assigned for field of activities in studies carried out on 4MAT model. Lesson plans for 4MAT model was employed in teaching the treatment group while control group was taught using 7th grade textbook. Transformation Geometry Knowledge Test designed by the researcher was the instrument used for data collection. The result of the study in relation to academic achievement and retention revealed a substantial difference favoring the treatment group.

Back in Benue state Nigeria, the study by Kurumeh, Onah, and Mohammed (2012) aimed at investigating the effect of the ethnomathematics teaching strategy and gender on Junior Secondary three (JS3) students' retention in statistics employed quasiexperimental design. Intact classes were used for both the experimental and control groups. Ethnomathematics teaching strategy was employed in teaching experimental group while control group was taught using conventional teaching strategy. The instrument, the Statistics Retention Test (SRT) with reliability coefficient of 0.80 was employed for data collection. In analyzing the data, descriptive and inferential statistics such as Mean and Standard deviation and ANCOVA were used to test the research questions and null hypotheses at a 0.05 level of significance. The result of the study revealed that there was significant difference on retention between student taught using ethnomathematics teaching strategy and conventional teaching stategy in favour of ethnomathematics teaching strategy. In relation to gender achievement, there was no significant difference between ethnomathematics teaching approach and conventional approach based on gender. Thus, it was recommended that ethnomathematics teaching strategy be embraced in schools as it has demonstrated to be a workable alternative in supporting meaningful learning and positively affected students' retention of achievement.

Likewise, the study in Ilorin, Nigeria, performed by Adeniji, Ameen, Dambatta, and Orilonise (2018), on the impact of mastery learning on senior secondary school students' achievement and retention in circle geometry. The study employed a quasi-experimental design. 172 high school students were selected through a multi-stage sampling technique. Circle Geometry Achievement Test (CGAT) was the instrument used for collecting data. The study was however authenticated of its validity by an expert and test retest was employed for determining the reliability of the instrument, 0.82 was however obtained which is reliable. The result of the study indicated a substantial difference in favors of treatment group. No gender difference was noticed on the achievement. Similarly, no difference was noticed on the achievement of low, medium and high scoring students in the treatment group. In the same vain, in the posttest mean achievement and retention score a substantial difference was found. In the light of the above, it was therefore suggested that mathematics teachers should be trained on the effective utilization of mastery learning technique for improved mathematics achievement.

Furthermore, Makinde and Yusuf (2018) in Lagos state of Nigeria, investigated the impact of flipped classroom among high school students' achievement and retention in mathematics. The study employed a quasi-experimental design with sample drawn from 268 high school students randomly assigned to experimental and control groups (145 in experimental group and 123 in control group). Performance test was the instrument employed for data collection with reliability coefficient of 0.88 using Cronbach Alpha. ANCOVA was however used for data analysis. The result of the study shows a substantial difference favoring treatment group. The result also revealed treatment improves learners' retention of achievement in mathematics. It was in view of this that flipped classroom approach was recommended as it enhanced students' academic achievement and retention.

Earlier before the above study, Agwagah (1994) studied the effect of instruction in mathematics reading on pupil's achievement and retention in mathematics. The objective of the study was to find out the effect of instruction in mathematics reading on the achievement and retention of rural primary school pupils in addition and subtraction of numbers. Two research hypotheses guided the study and quasiexperimental research design was adopted. 142 primary four pupils randomly selected from two rural primary schools, one each from Anambra and Enugu states of Nigeria form the sample for the study. ANCOVA was used in analysing the data collected and findings indicated that those students who were taught mathematics reading performed better and retained more of the content taught. These study by Agwagah (1994) is related to the present study in terms of design and approach to data analysis. Conversely, it differs in scope and sample.

The study of Haghighi (2013) targeted at finding out the effects of brain-based learning in sophomore students' academic achievement and retention. Quasi experimental design was employed to Civil Aviation Technology College in Tehran, Iran. The study lasted for 16 weeks. The experimental group was taught using brain-based learning approach, while the control group was taught with conventional teaching approach. The finding of the study revealed that there was substantial difference on achievement and retention in favour of brainbased learning. 
Stimulated by the aforementioned studies related to the retention and academic achievement, the present study intended to investigate on the possible positive effect of van Hiele phased-based teaching strategy on retention of achievement of pre-service mathematics teacher in geometry. This will therefore serves to assist learners in the recall of geometry ideas, thereby enhancing and promoting learners' overall academic achievement in geometry.

\section{Objectives of the Study}

The purpose of this study is to determine the effects of van Hiele's phase-based teaching strategy and gender on pre-service mathematics teachers' retention of achievement in geometry in Niger state, Nigeria.

Specifically, the research objectives were as follows:

1. Determine the main effect of teaching method on pre-service mathematics teachers' retention of achievement in geometry.

2. Determine the main effect of gender on pre-service mathematics teachers' retention of achievement in geometry.

3. Determine the interaction effect of teaching method and gender on pre-service mathematics teachers' retention of achievement in geometry.

\section{Null Hypotheses}

The null hypotheses of the study were as follows:

Ho1 There is no significant main effect of teaching method on pre-service mathematics teachers' retention of achievement in geometry.

Ho2 There is no significant main effect of gender on pre-service mathematics teachers' retention of achievement in geometry.

Ho3 There is no significant interaction effect of teaching method and gender on Pre-service Mathematics Teachers'retention of achievement in geometry.

\section{METHODOLOGY}

\section{Research Design}

In this study, pretest and posttest quasi experimental design using a two-by-two (2x2) factorial design was employed with one experimental and control group. This design indicates two levels of treatment (van Hiele's phase-based teaching strategy and conventional teaching strategy) and two levels of gender (male and female).

The sample of this study involved 149 pre-service mathematics teachers presently registered (2017/2018 session) in MAT 122 (coordinate geometry) from two purposively selected colleges of education in Niger State, Nigeria. Purposive sampling technique was employed to get the 100 level pre-service mathematics teachers. The motive for selecting 100 level pre-service mathematics teachers is for the reason that MAT 122 is a course to be studied at that level. In addition, to make ready the pre-service mathematics teachers to teach learners based on secondary school content. Two course lecturers handling MAT 122 were purposively and carefully chosen, one each from the choosen colleges. The sample size of the pre-service mathematics teachers in the experimental and control group are 86 (62 male and 24 female) and 63 (54 male and 9 female) respectively captured from the intact class.

Cognitive Development and Achievement in Geometry (CDAG) adapted from Usiskin (1982) was used for data collection. It is a very
Table 1. Mean and Standard Deviation of Experimental and Control Groups on GAT Retention Test Scores

\begin{tabular}{cccc}
\hline Treatment & $\mathbf{N}$ & $\overline{\boldsymbol{X}}$ & SD \\
\hline Exp group & 86 & 55.49 & 10.29 \\
\hline Contr group & 63 & 42.57 & 13.67 \\
\hline Total & $\mathbf{1 4 9}$ & $\mathbf{5 0 . 0 3}$ & $\mathbf{1 3 . 4 2}$ \\
\hline
\end{tabular}

popular geometric test instrument which has previously been employed in quite a lot of studies (Atebe, 2008; Baffoe \& Mereku, 2010; Burger \& Shaughnessy, 1986; Usiskin, 1982). In research work studying van Hiele level of understanding and achievement in geometry, CDAG was employed and demonstrated to be effective (Alex \& Mammen, 2012; Halat \& Sahin, 2008). The test instrument was validated by two senior lecturers of mathematics education department one each from sampled colleges and one expert in the field of mathematics education from the university. The items were corrected and modified on the basis of suggestions and recommendations by the experts. The reliability coefficient for the GAT was found to be 0.79 which is considered reliable (Pallant, 2010; Wells \& Wollack, 2003).

The entire study lasted for 12 weeks. The first week was spent on administering pre-test on GAT to the two colleges involved in the study, the College of Education A and College of Education B. This was followed by application of treatment; the van Hiele's phase-based teaching strategy by the assigned mathematics lecturer to the experimental group and conventional teaching strategy to the control group for six weeks. Both groups were taught the same contents. The posttest, which is identical to pretest, was administered at the eight weeks of the experiment. Lastly, the retention test was administered four weeks after the retention test.

Descriptive statistics such as mean and standard deviation was used to answer all the research questions. Analysis of covariance (ANCOVA) statistics in Statistical Package for Social Sciences (SPSS) version 22.0 was used to test all the hypotheses at 0.05 , alpha level of significance.

\section{RESULTS}

Table 1 presents the retention mean achievement scores and standard deviation of experimental and control groups. From the table, the retention mean score and standard deviation of pre-service mathematics teachers in the experimental group is 55.49 and 10.29 while the control group had mean retention score and standard deviation of 42.57 and 13.67 respectively. The retention score of experimental groups is higher mean than that of the control group. This implies that the experimental group has a higher mean retention test score than the control group. As a result of this detected difference in mean retention scores, hypothesis Ho1 was tested at 0.05 level to determine if the observed difference was significant.

Table 2 presents the mean and standard deviation of retention test based on gender. From the table, the retention mean score and standard deviation of male pre-service mathematics teachers is 49.20 with a standard deviation of 13.38 while for the females, the mean attitude scores and standard deviations were 52.94 and 13.36 respectively. This implies that female achieved higher than males considering their higher mean scores at retention test. As a result of this observed difference in mean retention test scores, hypothesis Ho2 was tested at 0.05 levels to determine if the observed difference was significant. 
Table 2. Mean and Standard Deviation of GAT Retention Test Scores by Gender

\begin{tabular}{cccc}
\hline Gender & $\mathbf{N}$ & $\overline{\boldsymbol{X}}$ & SD \\
\hline Male & 116 & 49.20 & 13.38 \\
\hline Female & 33 & 52.94 & 13.36 \\
\hline Total & $\mathbf{1 4 9}$ & $\mathbf{5 0 . 0 3}$ & $\mathbf{1 3 . 4 2}$ \\
\hline
\end{tabular}

Table 3. Retention Means Scores on the Basis of Interaction Strategies (Treatment and Gender

\begin{tabular}{ccc}
\hline Treatment & Gender & $\begin{array}{c}\text { Retention score } \\
\text { Mean }(\overline{\boldsymbol{X}})\end{array}$ \\
\hline Experimental group & Male & 58.83 \\
\hline & Female & 58.76 \\
\hline Control group & Male & 38.70 \\
\hline & Female & 34.03 \\
\hline
\end{tabular}

Table 4. Summary of Analysis of Covariance (ANCOVA) Result of GAT Retention of Achievement Scores of Experimental and the Control Group

\begin{tabular}{ccccccc}
\hline Source & $\begin{array}{c}\text { Type III Sum } \\
\text { of Squares }\end{array}$ & Df & $\begin{array}{c}\text { Mean } \\
\text { Square }\end{array}$ & F & Sig. & $\begin{array}{c}\text { Partial } \\
\text { Eta } \\
\text { Squared }\end{array}$ \\
\hline Corrected Model & $21059.988^{\mathrm{a}}$ & 4 & 5264.997 & 135.582 & .000 & .790 \\
\hline Intercept & 9883.171 & 1 & 9883.171 & 254.507 & .000 & .639 \\
\hline Preachiev & 14919.799 & 1 & 14919.799 & 384.207 & .000 & .727 \\
\hline Treatment & 9641.710 & 1 & 9641.710 & 248.289 & .000 & .633 \\
\hline Gender & 118.263 & 1 & 118.263 & 3.045 & .083 & .021 \\
\hline $\begin{array}{c}\text { Treatment }{ }^{*} \\
\text { Gender }\end{array}$ & 113.173 & 1 & 113.173 & 2.914 & .090 & .020 \\
\hline Error & 5591.905 & 144 & 38.833 & & & \\
\hline Total & 399552.000 & 149 & & & & \\
\hline Corrected Total & 26651.893 & 148 & & & & \\
\hline
\end{tabular}

Table 3 shows mean retention scores of pre-service mathematics teachers on the basis of the interaction strategy of treatment and gender. An examination of the table revealed that male pre-service mathematics teachers in experimental group (van Hiele's phase-based teaching strategy) outperformed male pre-service mathematics teachers' in control group (conventional teaching strategy) in the retention scores. This is shown by the mean achievement score of 58.83 against 38.70. This trend was also observed for female pre-service mathematics teachers with mean achievement scores of 58.76 against 34.03 respectively. In view of this, male pre-service mathematics teachers performed better across different interaction strategies confirming the absence of any interaction between gender and instructional strategy in the retention test scores. Nevertheless, to determine if these observed differences were significant, hypotheses Ho3 was tested at 0.05 levels of significance.

Table 4 showed the ANCOVA result of the comparison of retention achievement scores of pre-service mathematics teachers in Experimental and Control Group using the pretest as a covariate. An examination of the table shows retention test scores for the main effect of treatment (i.e., teaching method), $\mathrm{F}(1,144)=248.29, \mathrm{p}<0.05$ ), partial eta squared $=.63$. On the basis of this, hypothesis Ho1 was rejected. This therefore suggest that there was significant difference between retention test scores of pre-service mathematics teachers taught using van Hiele's phase-based teaching strategy and those taught using conventional teaching strategy. In other word, those taught through van Hiele's phase based teaching strategy retained significantly more of what was taught than those taught through conventional teaching strategy. The main effect of gender on pre-service teachers retention of geometry was found to be non-significant given by $\mathrm{F}(1$, $144)=3.05, \mathrm{p}>0.05$, partial eta squared $=.021$ which implied that there is no significant main effect of gender on the retention achievement scores of pre-service mathematics teachers. Thus, hypothesis $\mathrm{Ho}_{\mathrm{O}}$ was failed to be rejected.

Similarly, there was no significant interaction effect of treatment and gender on pre-service mathematics teachers' retention scores given by $\mathrm{F}(1,144)=2.91, \mathrm{p}>0.05$, partial eta squared $=.020$. Therefore, hypothesis $\mathrm{H}_{0}$ was failed to be rejected. In other word, the effect of treatment (i.e., teaching method) on retention of achievement in geometry of the pre-service mathematics teachers on retention test scores does not depend on the gender of the pre-service mathematics teachers. This therefore suggest that, irrespective of gender, learning through van Hiele's phase based teaching strategy was significantly more effective in retaining the geometry achievement of pre-service mathematics teachers in comparison with conventional teaching strategy.

\section{DISCUSSION}

The effect of van Hiele's phase-based teaching strategy on preservice mathematics teachers' retention of achievement in geometry was investigated by hypotheses $\mathrm{HO}_{1}, \mathrm{H}_{2}$ and $\mathrm{HO}_{\mathrm{O}}$. The result shows that significant differences existed between the retention test scores of the two groups which is indicated in Table 1 with mean scores of 55.49 against 44.57 for experimental and control group respectively. This is further confirmed by ANCOVA result in Table 4 which shows that the retention of achievement of experimental and control groups differ significantly. The result indicated that treatment using van Hiele's phase-based teaching strategy produced significant difference on preservice mathematics teachers' retention of achievement in geometry.

It is on the basis of the above results that it was indicated by Kurumeh, Onah, and Mohammed (2012) that incorrect, insufficient and restricted teaching strategy employed by mathematics teachers is responsible for learners' inability to comprehend and recollect the rudimentary mathematical principles and logical facts. In view of this, Iji (2005) added that man is gifted with restricted ability for memorizing, therefore, to properly and efficiently apply all that was learnt, retention must have to play an important role. It is on the account of this that Van Hiele's phase-based teaching strategy was employed in this study to see if it will increase learners' retention of achievement in geometry. Nevertheless, the teaching strategy however proved to improve retention of achievement. The observed improvement may be credited to the uniqueness of the treatment administered. This result on retention is in consonance with the study of Khurana (2018) initiated in Delhi India, to find out the impact of hands-on activities in mathematics in relation to achievement and concept retention. 164 pupils form the sample of the study. A self-made test of concept retention was employed for data collection and t-test statistics was used in data analysis. The result of the study indicates a significant difference favouring the experimental group. For the retention of achievement, a significant difference was also noticed in favor of experimental group.

Similarly, the result of this study confirms the study carried out by Aliustaoğlu and Tuna (2018) which sought to find out the effects of 
4MAT model on the teaching of "Transformation Geometry". 4MAT model, is one of the current instructional strategy which provides basis for learner towards perceiving and processing knowledge. It was planned by taking into account the four learning styles in a way learner can discover a time interval appropriate for them. 61 high school students in a northern province of Turkey form the sample for the study. The study which lasted for 3 weeks adopt a pretest-posttest control group quasi-experimental design. The period of teaching was decided having in mind the time suggested in the textbook and the time assigned for field of activities in studies carried out on 4MAT model. Lesson plans for 4MAT model was employed in teaching the treatment group while control group was taught using 7th grade textbook. Transformation Geometry Knowledge Test designed by the researcher was the instrument used for data collection. The result of the study in relation to academic achievement and retention revealed a substantial difference favoring the treatment group.

Similarly, the result is in compliance with the study of Haghighi (2013) targeted at finding out the effects of brain-based learning in sophomore students' academic achievement and retention. Quasi experimental design was employed to Civil Aviation Technology College in Tehran, Iran. The study lasted for 16 weeks. The experimental group was taught using brain-based learning approach, while the control group was taught with conventional teaching approach. The finding of the study shows a substantial difference on achievement and retention in favour of brain-based learning. Also supporting this current study is the results of Kurumeh, Onah, and Mohammed (2012), Agwagah (1994), and Obi, Agwagah, and Agah (2014) whose studies were respectively meant to investigate the impact of the van Hiele model over conventional strategy on retention of achievement.

Likewise, in consistence with this study is the study carried out in Ilorin, Nigeria, by Adeniji, Ameen, Dambatta, and Orilonise (2018), on the impact of mastery learning on senior secondary school students' achievement and retention in circle geometry. The study employed a quasi-experimental design. 172 high school students were selected through a multi-stage sampling technique. Circle Geometry Achievement Test (CGAT) was the instrument used for collecting data. The study was however authenticated of its validity by an expert. Through test retest 0.82 was obtained as its reliability. The result of the study indicated a substantial difference in favors of treatment group. In the same vain, in the posttest mean achievement and retention score a substantial difference was found. It is on this note that it was suggested that mathematics teachers should be trained on the effective utilization of mastery learning technique for improved mathematic achievement.

The result of this study favouring treatment group could be attributed to view of Kurumeh (2012) who maintained that incorrect, insufficient and restricted teaching strategy employed by mathematics teachers is responsible for learners' inability to comprehend and recollect the rudimentary mathematical principles and logical facts.

The ANCOVA comparison of the retention mean scores based on gender was determined using hypothesis Hoz indicated in Table 4. The result indicated no significant difference existed between the retention score of male and female. Therefore, the result shows that gender had no influence on the retention of pre-service mathematics teachers. It can be deduced that the use of van Hiele phase-based teaching strategy enhanced the retention of both male and female pre-service mathematics teachers because of the uniqueness of the treatment instrument. This concurs with the result of Kurumeh et al. (2012) on the effect of the ethnomathematics teaching approach and gender on junior secondary three student retention who confirmed no substantial difference between treatment and control group. Supporting the above finding, the work of Obi, Agwagah, and Agah (2014) on effect of origami instructional approach is in agreement with the current study. The result revealed that the use of origami had no statistical differential effect on male and female.

\section{CONCLUSION/RECOMMENDATION}

Based on the finding of this study, significant difference existed on retention of achievement between pre-service mathematics teachers taught geometry using van Hiele phase-based teaching strategy and those taught using conventional teaching. To be specific, Van Hiele phase-based teaching strategy was found to be more effective in improving pre-service mathematics teachers' retention of achievement in geometry concepts. It was therefore concluded that the teaching strategy seems to be a solution to the poor academic achievement problem. In view of this, it was recommended that VPBTS should therefore be use by lecturers in teaching not only geometry but mathematics in general.

\section{REFERENCES}

Abdullah, A. H., \& Zakaria, E. (2013). The effects of van Hiele's phasebased instruction using the geometer's sketchpad (GSP) on students' levels of geometric thinking. Research Journal of Applied Sciences, Engineering and Technology, 5(5), 1652-1660. https://doi.org/10.19026/rjaset.5.4919

Abu, M. S., Ali, M. B., \& Hock, T. T. (2012). Assisting primary school children to progress through their van Hiele's levels of geometry thinking using Google SketchUp. Procedia-Social and Behavioral Sciences, 64, 75-84. https://doi.org/10.1016/j.sbspro.2012.11.010

Adeniji, S. M., Ameen, S. K., Dambatta, B. U., \& Orilonise, R. (2018). Effect of mastery learning approach on senior school students' academic performance and retention in circle geometry. International Journal of Instruction, 11(4), 951-962. https://doi.org/10.12973/iji.2018.11460a

Agwagah, U. N. V. (1994). Effect of instruction in mathematics reading on pupils' achievement and retention in mathematics education. Journal of Quality Education, 1(1), 67-72.

Alex, J. K., \& Mammen, K. J. (2012). A survey of South African grade 10 learners' geometric thinking levels in terms of the van Hiele theory. Anthropologist, 14(2), 123-129. https://doi.org/10.1080/ 09720073.2012.11891229

Alex, J. K., \& Mammen, K. J. (2016). Lessons learnt from employing van Hiele theory-based instruction in senior secondary school geometry classrooms. Eurasia Journal of Mathematics, Science \& Technology Education, 12(8), 2223-2236. https://doi.org/10.12973/ eurasia.2016.1228a

Aliustaoğlu, R. A. F., \& Tuna, A. (2018). The influence of 4MAT model on academic achievement and retention of learning in transformation geometry. International Journal on New Trends in Education \& their Implications (IJONTE), 9(2), 16-32. 
Asante, K. O. (2012). Secondary students' attitudes towards mathematics. IFE Psychologia: An International Journal, 20(1), 121133.

Atebe, H. U. (2008). Student's van Hiele levels of geometric thought and conception in plane geometry: a collective case study of Nigeria and South Africa (Unpublished doctoral dissertation), Rhodes University, South Africa.

Baffoe, E., \& Mmereku, D. K. (2010). The van Hiele levels of understanding of students entering senior high school in Ghana. African Journal of Educational Studies in Mathematics and Science, 8, 5161. https://doi.org/10.4314/ajesms.v8i1.69103

Bell, B. S., \& Kozlowski, S. W. (2008). Active learning: effects of core training design elements on self-regulatory processes, learning, and adaptability. Journal of Applied psychology, 93(2), 296 https://doi.org/10.1037/0021-9010.93.2.296

Burger, W. F., \& Shaughnessy, J. M. (1986). Characterizing the van Hiele levels of development in geometry. Journal for Research in Mathematics Education, 17(1), 31-48. https://doi.org/10.5951/ jresematheduc.17.1.0031

Cannizzaro, L., \& Menghini, M. (2006). From geometrical figures to definitional Rigour: Teachers' analysis of teaching units mediated through van Hiele's theory. Canadian Journal of Math, Science $\mathbb{E}$ Technology Education, 6(4), 369-386. https://doi.org/10.1080/ 14926150609556711

Chang, K. E., Sung, Y. T., \& Lin, S. Y. (2007). Developing geometry thinking through multimedia learning activities. Computers in Human Behavior, 23(5), 2212-2229. https://doi.org/10.1016/ j.chb.2006.03.007

Chew, C. M. (2007). Form one students' learning of solid geometry in a phase-based instructional environment using The Geometer's Sketchpad (Unpublished doctoral dissertation), Fakulti Pendidikan, Universiti Malaya, Malaysia.

Chew, C. M. (2009). Assessing pre-service secondary mathematics teachers' geometric thinking. Proceedings of the 5th Asian Mathematical Conference Penang, Malaysia.

Chew, C. M., \& Lim, C. S. (2013). Enhancing primary pupils' geometric thinking through phase-based instruction using the geometer's sketchpad. The Asia Pacific Journal of Educators and Education (formerly known as Journal of Educators and Education), 28(1), 1-19.

Choi-Koh, S. S. (2000). The activities based on van Hiele model using computer as a tool. Journal of the Korea Society of Mathematical Education Series D: Research in Mathematical Education, 4(2), 63-77.

Erdoğan, T., \& Durmuş, S. (2009). The effect of the instruction based on Van Hiele model on the geometrical thinking levels of preservice elementary school teachers. Procedia-Social and Behavioral Sciences, 1(1), 154-159. https://doi.org/10.1016/j.sbspro.2009.01.029

Eshun, B. (2004). Sex-differences in attitude of students towards mathematics in secondary schools. Mathematics Connection, 4(1), 113. https://doi.org/10.4314/mc.v4i1.21495

Fuys, D., Geddes, D., \& Tischler, R. (1988). The van Hiele model of thinking in geometry among adolescents. Journal for Research in Mathematics Education. Monograph, 3, i-196. https://doi.org/ $10.2307 / 749957$
Gambari, A. I., Falode, C. O., \& Adegbenro, D. A. (2014). Effectiveness of computer animation and geometrical instructional model on mathematics achievement and retention among junior secondary school students. European Journal of Science and Mathematics Education, 2(2), 127-146.

Haghighi, M. (2013). The effect of brain-based learning on iranian efl learners' achievement and retention. Procedia-Social and Behavioral Sciences, 70, 508-516. https://doi.org/10.1016/j.sbspro.2013.01.088

Halat, E. (2008). In-service middle and high school mathematics teachers: Geometric reasoning stages and gender. The Mathematics Educator, 18(1), 8-14.9

Hassan, A. A. (2015). Effect of van Hiele's geometric model on pedagogical abilities of nigeria certificate in education mathematics students in Niger state (Unpublished doctoral thesis), Ahmadu Bello University Zaria, Nigeria.

Hoffer, A. (1983). Van Hiele-based research. In R. Lesh \& M. Landau (Eds.) Acquisition of mathematics concepts and processes (pp. 205-227). New York: Academic Press

Iji, C. O., \& Harbour-Peters, V. F. (2005). Effects of logo and basic programs on the achievement in geometry of junior secondary school students. ABACUS, 30(1), 28-40.

Khurana, M. S. (2018). An experimental study of the effect of hands-on activities in mathematics in relation to achievement and concept retention of vii standard students in government schools of Delhi. Global Journal for Research Analysis, 6(11).

Kurumeh, M. S., Onah, F. O., \& Mohammed, A. S. (2012). Improving students 'retention in junior secondary school statistics using the ethno-mathematics teaching approach in Obi and Oju Local Government Areas of Benue State, Nigeria. Greener Journal of Educational research, 2(3), 54-62. https://doi.org/10.15580/ GJER.2012.3.10051286

Lindberg, S. M., Hyde, J. S., Petersen, J. L., \& Linn, M. C. (2010). New trends in gender and mathematics performance: a meta-analysis. Psychological Bulletin, 136(6), 1123-1135. https://doi.org/10.1037/ a0021276

Makinde, S. O., \& Yusuf, M. O. (2018). The flipped classroom: its effects on students' performance and retention in secondary school mathematics classroom. International Journal for Innovative Technology Integration in Education, 1(1), 117-126.

Mata, M. D. L., Monteiro, V., \& Peixoto, F. (2012). Attitudes towards mathematics: Effects of individual, motivational, and social support factors. Child development research, 2012. https://doi.org/10.1155/ 2012/876028

Mohamed, L., \& Waheed, H. (2012). Secondary students' attitude towards mathematics in a selected school of Maldives. International Journal of humanities and social science, 1(15), 277-281.

National Council of Teachers of Mathematics (2000). Principles and standards for school mathematics. Restoh, VA.: NCTM.

Obi, C. N., Agwagah, U. N. V., \& Agah, J. J. (2014). Effect of origami on students' retention in geometry. IOSR Journal of Research \& Method in Education (IOSR-JRME), 4(5), 46-50. https://doi.org/10.9790/ 7388-04514650 
Omenka, J. E (2010). Effect of ethnomathematics approach on Achievement and Attitude towards number and numeration among the junior secondary school students (Unpublished doctoral thesis), Benue state University, Makurdi.

Osemwinyen, A. C. (2009). Effects of e-learning on retention and achievement in secondary school mathematics in Abuja, Nigeria (Unpublished doctoral dissertation). University of Nigeria, Nsukka.

Pallant, J. (2010). SPSS survival manual: A step by step guide to data analysis using SPSS. Maidenhead, McGraw-Hill Education (UK). Retrieved from http://www.mheducation.co.uk/openup/chapters/0335208 908.pdf

Udousoro, U. J. (2002). The relative effects of computer and text-assisted programmed instruction on students' learning outcomes in mathematics (Unpublished doctoral thesis), University of Ibadan, Nigeria.

Usiskin, Z. (1982). van Hiele levels and achievement in secondary school geometry. (Final Report of the Cognitive Development and Achievement in Secondary School Geometry Project) Chicago: University of Chicago (ERIC Document Reproduction service Number ED220288).
Uygun, N., \& Tertemiz, N. I. (2014). Effects of problem-based learning on student attitudes, achievement and retention of learning in math course. Egitim ve Bilim, 39(174). https://doi.org/10.15390/ EB.2014.1975

Van Hiele, P. M. (1986). Structure and insight: a theory of mathematics education. Academic Pres. Inc: Orlando, Florida.

Wells, C. S., \& Wollack, J. A. (2003). An instructor's guide to understanding test reliability. Madison, WI: Testing and Evaluation Service, University of Wisconsin, Madison. Retrieved from http://testing.wisc.edu/Reliability.pdf

Yunus, M., Suraya, A., Ayub, M., \& Fauzi, A. (2019). Geometric Thinking of Malaysian Elementary School Students. International Journal of Instruction, 12(1), 1095-1112. https://doi.org/10.29333/ iji.2019.12170a 